\title{
Biomethanation of Syngas Using Anaerobic Sludge: Shift in the Catabolic Routes with the CO Partial Pressure Increase
}

\author{
Silvia Sancho Navarro ${ }^{1,2}$, Ruxandra Cimpoia ${ }^{1}$, Guillaume Bruant ${ }^{1}$ and Serge R. Guiot ${ }^{1,2 *}$ \\ ${ }^{1}$ Bioengineering Group, Energy, Mining and Environment, National Research Council Canada, Montreal, QC, Canada, \\ ${ }^{2}$ Department of Microbiology, Infectiology and Immunology, Université de Montréal, Montreal, QC, Canada
}

\section{OPEN ACCESS}

Edited by:

Madalena Santos Alves,

University of Minho, Portugal

Reviewed by:

Nuno Miguel Reis,

Loughborough University, UK

Christian Kennes,

Universidade da Coruña, Spain

*Correspondence:

Serge R. Guiot

serge.guiot@canada.ca

Specialty section:

This article was submitted to Microbiotechnology, Ecotoxicology and Bioremediation,

a section of the journal

Frontiers in Microbiology

Received: 25 February 2016

Accepted: 18 July 2016

Published: 03 August 2016

Citation:

Sancho Navarro S, Cimpoia $R$, Bruant $G$ and Guiot SR (2016)

Biomethanation of Syngas Using

Anaerobic Sludge: Shift in the Catabolic Routes with the CO Partial

Pressure Increase.

Front. Microbiol. 7:1188.

doi: 10.3389/fmicb.2016.01188
Syngas generated by thermal gasification of biomass or coal can be steam reformed and purified into methane, which could be used locally for energy needs, or re-injected in the natural gas grid. As an alternative to chemical catalysis, the main components of the syngas $\left(\mathrm{CO}, \mathrm{CO}_{2}\right.$, and $\left.\mathrm{H}_{2}\right)$ can be used as substrates by a wide range of microorganisms, to be converted into gas biofuels, including methane. This study evaluates the carboxydotrophic (CO-consuming) methanogenic potential present in an anaerobic sludge from an upflow anaerobic sludge bed (UASB) reactor treating waste water, and elucidates the $\mathrm{CO}$ conversion routes to methane at $35 \pm 3^{\circ} \mathrm{C}$. Kinetic activity tests under $\mathrm{CO}$ at partial pressures $\left(\mathrm{p}_{\mathrm{co}}\right)$ varying from 0.1 to $1.5 \mathrm{~atm}(0.09-1.31$ $\mathrm{mmol} / \mathrm{L}$ in the liquid phase) showed a significant carboxydotrophic activity potential for growing conditions on $\mathrm{CO}$ alone. A maximum methanogenic activity of $1 \mathrm{mmol}$ $\mathrm{CH}_{4}$ per $\mathrm{g}$ of volatile suspended solid and per day was achieved at $0.2 \mathrm{~atm}$ of $\mathrm{CO}$ $(0.17 \mathrm{mmol} / \mathrm{L})$, and then the rate decreased with the amount of $\mathrm{CO}$ supplied. The intermediary metabolites such as acetate, $\mathrm{H}_{2}$, and propionate started to accumulate at higher $\mathrm{CO}$ concentrations. Inhibition experiments with 2-bromoethanesulfonic acid (BES), fluoroacetate, and vancomycin showed that in a mixed culture CO was converted mainly to acetate by acetogenic bacteria, which was further transformed to methane by acetoclastic methanogens, while direct methanogenic $\mathrm{CO}$ conversion was negligible. Methanogenesis was totally blocked at high $p_{c o}$ in the bottles ( $\left.\geq 1 \mathrm{~atm}\right)$. However it was possible to achieve higher methanogenic potential under a 100\% CO atmosphere after acclimation of the sludge to $\mathrm{CO}$. This adaptation to high $\mathrm{CO}$ concentrations led to a shift in the archaeal population, then dominated by hydrogen-utilizing methanogens, which were able to take over acetoclastic methanogens, while syntrophic acetate oxidizing (SAO) bacteria oxidized acetate into $\mathrm{CO}_{2}$ and $\mathrm{H}_{2}$. The disaggregation of the granular sludge showed a negative impact on their methanogenic activity, confirming that the acetoclastic methanogens were the most sensitive to $\mathrm{CO}$, and a contrario, the advantage of using granular sludge for further development toward large-scale methane production from CO-rich syngas.

Keywords: syngas, carbon monoxide, anaerobic, methanation, carboxydotrophic methanogenesis, syntrophic acetate oxidation 


\section{INTRODUCTION}

Synthesis gas, or "syngas," produced by thermal gasification of biomass has received increased attention for energy recovery in the past decades due to its higher efficiency compared to other bioenergy processes (McKendry, 2002; Huber et al., 2006). The principal components of syngas, carbon monoxide (CO), carbon dioxide $\left(\mathrm{CO}_{2}\right)$, and hydrogen $\left(\mathrm{H}_{2}\right)$, can serve as substrates for the production of chemicals and fuels, namely methane, through a wide range of microorganisms (Klasson et al., 1991; Sipma et al., 2003; Guiot et al., 2011; Alves et al., 2013; Abubackar et al., 2015). Biomethane can therefore be used to replace natural gas extracted from fossil fuel sources and re-injected into the natural gas grid. However thus far, few microorganisms able to reduce syngas' CO into methane have been discovered (Daniels et al., 1977; Rother and Metcalf, 2004; Oelgeschläger and Rother, 2008; Ferry, 2010). A good source of carboxydotrophic (CO-consuming) microorganisms is anaerobic wastewater-treating sludge, which can be exploited for methane production at large scale (Sipma et al., 2004; Guiot et al., 2011).

The anaerobic conversion of $\mathrm{CO}$ can support a variety of microorganisms from different trophic groups within a microbial community. Therefore the pathways involved in methane production from $\mathrm{CO}$ become more complex when working with a mixed anaerobic consortium. Carbon monoxide dehydrogenase $(\mathrm{CODH})$ is the enzyme involved in the $\mathrm{CO}$ oxidation according to: $\mathrm{CO}+\mathrm{H}_{2} \mathrm{O} \rightarrow \mathrm{CO}_{2}+2 \mathrm{H}^{+}+2 \mathrm{e}^{-}$. This enzyme is present in all carboxydotrophic microorganisms currently known, including methanogens. The oxidation of $\mathrm{CO}$ by the $\mathrm{CODH}$ provides the energy required to reduce the different substrates in order to produce $\mathrm{H}_{2}$, acetate, and methane (Thauer et al., 1977). Recent studies have pointed out that the electron production from $\mathrm{CO}$ is thermodynamically favorable in comparison to $\mathrm{H}_{2}$, and thus $\mathrm{CO}$ can theoretically replace $\mathrm{H}_{2}$ as the electron donor in all the microorganisms that contain CODH (Oelgeschläger and Rother, 2008; Hu et al., 2011).

CO can be metabolized by four main trophic groups of microorganisms: methanogenic (methane-producing) archaea, hydrogenogenic (hydrogen-producing) bacteria, acetogenic (acetate-producing) bacteria, and sulfate-reducing bacteria (Mörsdorf et al., 1992; Oelgeschläger and Rother, 2008). Thus, when working with a mixed methanogenic culture it is essential to consider all possible reactions, which are involved in the conversion of CO to methane. Carboxydotrophic methanogenic archaea are able to convert $\mathrm{CO}$ directly to methane through the following reaction:

$$
4 \mathrm{CO}+2 \mathrm{H}_{2} \mathrm{O} \rightarrow \mathrm{CH}_{4}+3 \mathrm{CO}_{2}\left(\Delta \mathrm{G}^{\circ \prime}=-212 \mathrm{~kJ} / \text { reaction }\right)
$$

However, methane can also be produced from $\mathrm{CO}$ indirectly via other metabolites such as $\mathrm{H}_{2}$ and $\mathrm{CO}_{2}$ or formate, produced by hydrogenogenic fermentation, followed by hydrogenotrophic methanogenesis, or acetate produced from $\mathrm{CO}$ by acetogenic bacteria with subsequent acetoclastic methanogenesis. The main indirect carboxydotrophic methanogenic reactions can be summarized as follows:

$$
\begin{aligned}
& \mathrm{CO}+\mathrm{H}_{2} \mathrm{O} \rightarrow \mathrm{H}_{2}+\mathrm{CO}_{2}\left(\Delta \mathrm{G}^{\circ \prime}=-20 \mathrm{~kJ} / \text { reaction }\right) \text { (2a) } \\
& \mathrm{CO}_{2}+4 \mathrm{H}_{2} \rightarrow \mathrm{CH}_{4}+2 \mathrm{H}_{2} \mathrm{O}\left(\Delta \mathrm{G}^{\circ \prime}=-131 \mathrm{~kJ} / \text { reaction }\right)(2 \mathrm{~b}) \\
& \mathrm{CO}+3 \mathrm{H}_{2} \rightarrow \mathrm{CH}_{4}+\mathrm{H}_{2} \mathrm{O}\left(\Delta \mathrm{G}^{\circ \prime}=-151 \mathrm{~kJ} / \text { reaction }\right) \\
& \mathrm{CO}+\mathrm{H}_{2} \mathrm{O} \rightarrow \mathrm{HCOOH}\left(\Delta \mathrm{G}^{\circ \prime}=-16 \mathrm{~kJ} / \text { reaction }\right) \\
& 4 \mathrm{HCOOH}+\mathrm{H}_{2} \mathrm{O} \rightarrow \mathrm{CH}_{4}+3 \mathrm{CO}_{2}+3 \mathrm{H}_{2} \mathrm{O} \\
& \left(\Delta \mathrm{G}^{\circ \prime}=-145 \mathrm{~kJ} / \text { reaction }\right) \\
& 4 \mathrm{CO}+2 \mathrm{H}_{2} \mathrm{O} \rightarrow \mathrm{CH}_{3} \mathrm{COOH}+2 \mathrm{CO}_{2} \\
& \left(\Delta \mathrm{G}^{\circ \prime}=-176 \mathrm{~kJ} / \text { reaction }\right) \\
& \mathrm{CH}_{3} \mathrm{COOH} \rightarrow \mathrm{CH}_{4}+\mathrm{CO}_{2}\left(\Delta \mathrm{G}^{\circ \prime}=-31 \mathrm{~kJ} / \text { reaction }\right)
\end{aligned}
$$

When combining either the reactions (2a) and (2b), or (2a) and $(2 c)$, or $(3 a)$ and $(3 b)$, or $(4 a)$ and (4b), the net production of methane from $\mathrm{CO}$ occurs in all cases as follows:

$$
4 \mathrm{CO}+2 \mathrm{H}_{2} \mathrm{O} \rightarrow \mathrm{CH}_{4}+3 \mathrm{CO}_{2}
$$

In addition, homoacetogenic bacteria can participate in the conversion of the $\mathrm{H}_{2}$ and $\mathrm{CO}_{2}$ to acetate, a thermodynamically favorable reaction, as follows:

$$
\begin{aligned}
& 4 \mathrm{H}_{2}+2 \mathrm{CO}_{2} \rightarrow \mathrm{CH}_{3} \mathrm{COOH}+2 \mathrm{H}_{2} \mathrm{OG}^{\circ \prime} \\
&\left(\Delta \mathrm{G}^{\circ \prime}=-104 \mathrm{k} J / \text { reaction }\right)
\end{aligned}
$$

Conversely, syntrophic acetate-oxidizing (SAO) bacteria can convert acetate to $\mathrm{H}_{2}$ and $\mathrm{CO}_{2}$ when acetoclastic methanogenesis (reaction 4b) is deficient (Karakashev et al., 2006), as follows:

$\mathrm{CH}_{3} \mathrm{COOH}+2 \mathrm{H}_{2} \mathrm{O} \rightarrow 4 \mathrm{H}_{2}+2 \mathrm{CO}_{2}\left(\Delta \mathrm{G}^{\circ \prime}=+95 \mathrm{~kJ} /\right.$ reaction $)$

The SAO reaction becomes thermodynamically favorable at low $\mathrm{H}_{2}$ partial pressure $\left(<10^{-4}\right.$ atm at $\left.35^{\circ} \mathrm{C}\right)$ (Lee and Zinder, 1988; Cord-Ruwisch et al., 1998). Moreover, some carboxydotrophic bacteria are able to convert $\mathrm{CO}$ into other metabolites such as ethanol, propionate, butyrate, and butanol, as follows:

$$
\begin{aligned}
& 6 \mathrm{CO}+3 \mathrm{H}_{2} \mathrm{O} \rightarrow \mathrm{CH}_{3} \mathrm{CH}_{2} \mathrm{OH}+4 \mathrm{CO}_{2} \\
&\left(\Delta \mathrm{G}^{\circ \prime}=-222 \mathrm{~kJ} / \text { reaction }\right) \\
& 7 \mathrm{CO}+3 \mathrm{H}_{2} \mathrm{O} \rightarrow \mathrm{CH}_{3} \mathrm{CH}_{2} \mathrm{COOH}+4 \mathrm{CO}_{2} \\
&\left(\Delta \mathrm{G}^{\circ \prime}=-308 \mathrm{~kJ} / \text { reaction }\right) \\
& 10 \mathrm{CO}+4 \mathrm{H}_{2} \mathrm{O} \rightarrow \mathrm{CH}_{3}\left(\mathrm{CH}_{2}\right)_{2} \mathrm{COOH}+6 \mathrm{CO}_{2} \\
&\left(\Delta \mathrm{G}^{\circ \prime}=-440 \mathrm{~kJ} / \text { reaction }\right) \\
& 12 \mathrm{CO}+5 \mathrm{H}_{2} \mathrm{O} \rightarrow \mathrm{CH}_{3}\left(\mathrm{CH}_{2}\right)_{3} \mathrm{OH}+8 \mathrm{CO}_{2} \\
&\left(\Delta \mathrm{G}^{\circ \prime}=-480 \mathrm{~kJ} / \text { reaction }\right)
\end{aligned}
$$

All the above products can then be converted into methane indirectly via acetate and $\mathrm{H}_{2} / \mathrm{CO}_{2}$ (Mazumder et al., 1985; Liou et al., 2005; Henstra et al., 2007).

To enhance the carboxydotrophic methanogenic potential of natural mixed anaerobic cultures and to further facilitate the reactor's scale-up and optimization, it is important to understand the prevalent metabolic pathways of the microorganisms and 
how the metabolism is affected by environmental conditions. To address this issue this study is focused on the assessment of the carboxydotrophic methanogenic potential present in an anaerobic wastewater-treating sludge from an upflow anaerobic sludge bed (UASB) reactor as well as the identification of $\mathrm{CO}$ conversion routes to methane under mesophilic temperatures with the use of specific metabolic inhibitors for bacteria and archaea (methanogens). The experimental design includes an evaluation of the impact of variables such as the substrate concentration and the biomass morphology, on the carboxydotrophic methanogenic potential of the sludge.

\section{MATERIALS AND METHODS}

\section{Sludge}

The tests carried out for this study were performed under mesophilic conditions $\left(35^{\circ} \mathrm{C}\right)$, using anaerobic granular sludge from a full-scale upflow anaerobic sludge blanket (UASB) plant treating fruit processing wastewater (Lassonde Inc., Rougemont, QC, Canada). To disaggregate the granules, the sludge was sieved using a mesh grid with $0.25-\mathrm{mm}$ openings and crushed with a mortar under a $\mathrm{N}_{2}$ atmosphere. The sieved-crushed sludge was resuspended in $0.05 \mathrm{M}$ phosphate buffer at $\mathrm{pH}$ 7.5.

\section{Experimental Design Identification of Methanogenic Carboxydotrophic Potential and Toxicity}

Carboxydotrophic and methanogenic specific activity tests were performed in triplicate on the suspended anaerobic sludge as well as on whole granules. The tests were carried out with $\mathrm{CO}$ as the sole substrate in $60 \mathrm{~mL}$ serum bottles. The bottles were filled with $20 \mathrm{~mL}$ of the inoculum diluted with $0.05 \mathrm{M}$ phosphate buffer at $\mathrm{pH} 7.5$ to an initial concentration of $2 \mathrm{~g}$ volatile suspended solids (VSS)/L. To establish anaerobic conditions the bottles were capped, sealed with butyl rubber stoppers and flushed with $\mathrm{N}_{2}$ gas (100\%) for $3 \mathrm{~min}$. Afterwards the CO was injected into the bottles under anaerobic conditions. The $\mathrm{CO}$ partial pressure ( $\mathrm{p}_{\mathrm{CO}}$ ) ranged between 0.1 and 1.5 atm (20-100\% CO, $\mathrm{N}_{2}$ balance), and corresponded to $\mathrm{CO}$ concentrations in liquid varying from 0.09 to $1.31 \mathrm{mM}$, using a value of $1148 \mathrm{~atm} . \mathrm{L} / \mathrm{mol}$ for the Henry constant at $35^{\circ} \mathrm{C}$ in a buffered media (Zhao et al., 2013). For the tests at a $\mathrm{p}_{\mathrm{CO}}$ lower than $1 \mathrm{~atm}$, a volume of $\mathrm{N}_{2}$ is removed from the bottle and replaced by an equivalent volume of $\mathrm{CO}$ using a gas tight syringe to obtain the required $\mathrm{p}_{\mathrm{CO}}$ in the headspace. For the test at $1 \mathrm{~atm}$ of $\mathrm{CO}$ or more, all headspace $\mathrm{N}_{2}$ is replaced with $\mathrm{CO}$ using the manometer of the $\mathrm{CO}$ cylinder line to adjust the microcosm headspace to the desired pCO. The bottles were immediately placed in dark environmental conditions in a rotary shaker (New Brunswick, Edison, NJ) controlled thermostatically at $35 \pm 3^{\circ} \mathrm{C}$ and operated at $200 \mathrm{rpm}$ to maximize the gasliquid mass transfer. During the incubation period the bottles' headspace was sampled for $\mathrm{CH}_{4}, \mathrm{H}_{2}$ and $\mathrm{CO}$ analysis by gas chromatography at regular time intervals depending on the initial $\mathrm{CO}$ concentration until the $\mathrm{CO}$ was totally depleted. From the chromatogram, the volume for each gas species measured was computed into mmol per bottle, knowing the temperature of the sample, the volume of injection at standard pressure and the volume of the bottle's headspace. The gas dissolved in the liquid has been neglected as it represents less than $1.5 \%$ of the total amount. The bottles' gas content-time curves were drawn using a smoothing curve fit function (KaleidaGraph 4.5, Synergy Software, Reading, PA), which applies the Stineman algorithm to the data (Stineman, 1980). The output of this function has a geometric weight applied to the current point and $\pm 10 \%$ of the data range, to arrive at the smoothed curve. The maximum CO consumption or $\mathrm{CH}_{4}$ production rates were calculated by a leastsquares-based linear regression over three to six values around the inflection point of the $\mathrm{CO}$ depletion and $\mathrm{CH}_{4}$ accumulation time-courses. The specific activity was obtained by dividing the consumption or production rate by the VSS content in the serum bottle, and expressed in mmol of $\mathrm{CO}$ or $\mathrm{CH}_{4}$ per gram of VSS per day, as formerly described (Guiot et al., 1995, 2011). At the end of each assay liquid samples from each bottle were analyzed for the presence of volatile fatty acids (VFA) and alcohols.

Four control tests were also performed: an endogenous activity test (without substrate), an inhibited endogenous activity test (with cyanide), a negative control (with CO and cyanide), and lastly an abiotic test (with a basal medium without sludge).

\section{Identification of Possible Routes to Methane}

To identify the actual routes for CO conversion to methane, assays were carried out with inhibitors. The tests were performed in the same manner as described above, however the bottles were injected at the start of the test, prior to incubation, with the specific metabolic inhibitors: $50 \mathrm{mM}$ 2-bromoethane sulfonic acid (BES) (sodium salt, 98\% purity, SigmaAldrich, Netherlands), used as a methanogenic inhibitor, $5 \mathrm{mM}$ fluoroacetic acid (FA) (sodium salt, 98\% purity, Sigma-Aldrich, USA), used as inhibitor of the acetate catabolism (Banat et al., 1981; Chidthaisong and Conrad, 2000), or $0.07 \mathrm{mM}$ vancomycin (hydrochloride hydrate, Sigma-Aldrich, USA) inhibitor of grampositive bacteria (Nicklin et al., 1999), generally including acetogenic bacteria. The specific concentrations of the inhibitors were chosen from metabolic studies in the literature on the efficiency of the inhibitory effect on the desired activity (Banat et al., 1981; Bagley and Gossett, 1990; Sipma et al., 2004; Sancho Navarro et al., 2014). All of the inhibitory tests were carried out in duplicate. The impact of the three inhibitors mentioned above on the different pathways of $\mathrm{CH}_{4}$ production from $\mathrm{CO}$ are graphically summarized in Figure 1.

\section{Effect of a Long-Time Exposure of the Anaerobic Sludge to $\mathrm{CO}$}

To evaluate the effect of a long-time exposure to high $\mathrm{CO}$ concentrations on the carboxydotrophic and methanogenic microbial populations, further activity tests were carried out similarly as described above. For that purpose the disaggregated sludge was incubated during 45 days with continuous $\mathrm{CO}$ injections in the headspace, creating an atmosphere of $100 \%$ CO. In addition, denaturing gradient gel electrophoresis (DGGE) experiments were performed in parallel to examine changes in the microbial community structure over the time. Samples for DGGE analyses were taken from the bottles after one month and at the end of the 45 days incubation period. 
A (Vancomycin)

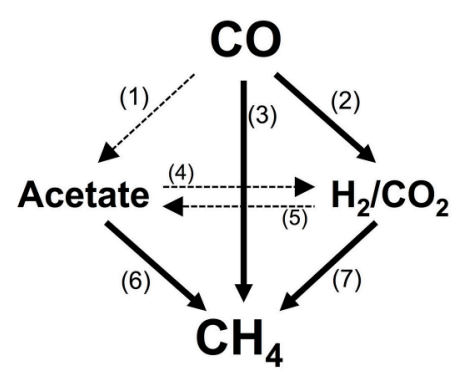

в (BES)

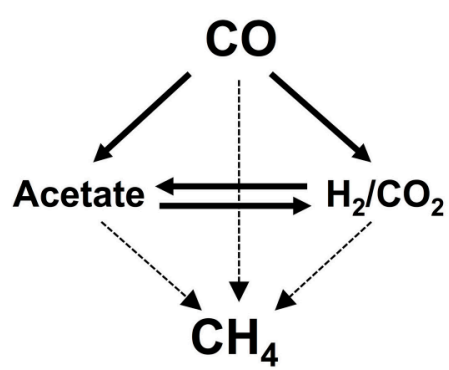

c (FA)

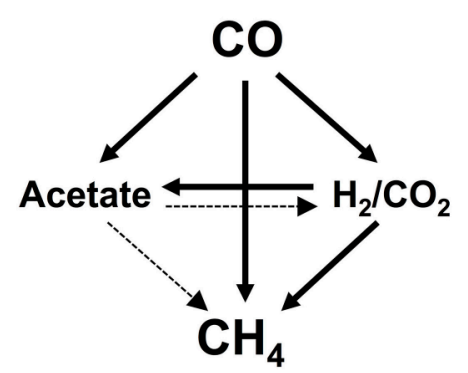

FIGURE 1 | Possible catabolic routes from CO to methane in presence of vancomycin (A), 2-bromoethane sulfonate (BES) (B), and fluoroacetate (FA) (C). The solid arrows indicate the pathways available in presence of the inhibitor; the dotted arrows indicate pathways blocked in presence of the inhibitor, totally or partially, in the case of vancomycin, as gram negative bacteria remain active. Pathways: (1), carboxydotrophic acetogenesis; (2), carboxydotrophic hydrogenogenesis; (3), carboxydotrophic methanogenesis; (4), syntrophic acetate oxidation; (5), homoacetogenesis; (6), acetoclastic methanogenesis; (7), hydrogenotrophic methanogenesis.

\section{Genomic Analyses}

Total genomic DNA was extracted from $2 \mathrm{~mL}$ homogenized sludge samples as previously described (Lévesque et al., 1997; Tresse et al., 2002), and then purified and concentrated using a QIAEX gel extraction kit (Hoffman-La Roche AG, USA) according to the manufacturer's instructions. DGGE experiments were performed as previously described (Tresse et al., 2005). Briefly, 16S rDNA sequences were amplified using the primers $341 \mathrm{f}\left(5^{\prime}\right.$-CCTACGGGAGGCAGCAG-3') (Muyzer et al., 1993) and 758r (5'-CTACCAGGGTATCTAATCC-3') (Lee et al., 1993) for Eubacteria, and the primers 931f (5' AGGAATTGGCGGGGGAGCA- 3') (Einen et al., 2008) and 1392r (5' - ACGGGCGGTGTGTAC - 3') (Kozubal et al., 2008) for Archaea. After electrophoresis, bands of interest were excised from the gel, re-amplified, and submitted to sequencing (Université Laval, Québec, QC, Canada). The sequences were analyzed and then compared to those in the GenBank database using the Basic Local Alignment Search Tool (BLAST) at the National Center for Biotechnology Information (NCBI) to determine the phylogenetic affiliations.

\section{Analytical Methods}

The gas components $\left(\mathrm{O}_{2}, \mathrm{H}_{2}, \mathrm{CH}_{4}, \mathrm{~N}_{2}, \mathrm{CO}, \mathrm{CO}_{2}\right)$ were determined by gas chromatography. Gas sample of $300 \mu \mathrm{L}$ (model 1750 gas-tight syringe, Hamilton, Reno, NV) was injected on an Agilent 6890 gas chromatograph (Wilmington, DE) equipped with a TCD and a $5 \mathrm{~m} \times 2.1 \mathrm{~mm}$ Carboxen-1000 column (Supelco, Bellafonte, PA) with argon as a carrier gas. The column temperature was held at $60^{\circ} \mathrm{C}$ for $7 \mathrm{~min}$ and increased to $225^{\circ} \mathrm{C}$ at a rate of $60^{\circ} \mathrm{C}$ per min. Volatile fatty acids (VFA) (acetate, propionate, and butyrate) and alcohols (methanol, ethanol, acetone, 2-propanol, tert-butanol, n-propanol, secbutanol, and n-butanol) were measured on an Agilent 6890 gas chromatograph (Wilmington, DE) equipped with a flame ionization detector (FID) as described previously (Guiot et al., 2011). The volatile solids (VS), VSS, and chemical oxygen demand (COD) analyses were performed according to standard methods (Eaton et al., 1995).

\section{RESULTS}

\section{Carboxydotrophic Methanogenic Potential}

The disaggregated anaerobic sludge granules were first characterized for their carboxydotrophic and methanogenic potential at different $\mathrm{CO}$ partial pressure ( $\mathrm{p}_{\mathrm{CO}}$ ) in the gas phase. Typical time courses of CO depletion and hydrogen and methane production at a PCO $_{\text {of }} 0.2$ atm are shown in Figure 2A. Although the sludge was non-adapted, the lag time observed was short at low $\mathrm{P}_{\mathrm{CO}}$, and complete $\mathrm{CO}$ depletion occurred within two days. Generally accumulation of $\mathrm{H}_{2}$ was detected in the bottles, achieving highest $\mathrm{H}_{2}$ concentrations when the carboxydotrophic activity was maximal, after which hydrogen declined while the methane production rate appeared to increase.

Since CO is known to act as an inhibitor of methanogenesis, a kinetic activity test was performed to define the optimal CO concentration required to achieve maximum carboxydotrophic and methanogenic activities. The tests were carried out under different initial partial pressures of $\mathrm{CO}$ varying from 0.1 to $1.5 \mathrm{~atm}(0.09-1.31 \mathrm{mmol} / \mathrm{L}$ in the liquid phase), at mesophilic conditions $\left(35 \pm 3^{\circ} \mathrm{C}\right)$ (Table 1). The carboxydotrophic activities observed ranged between 1.8 and $8.6 \mathrm{mmol} \mathrm{CO}$ consumed per $\mathrm{g}$ VSS per day. The CO activity increased with the amount of CO supplied, and reached its maximum at a $\mathrm{p}_{\mathrm{CO}}$ of $0.5 \mathrm{~atm}$ in the gas phase $\left(0.44 \mathrm{mM}\right.$ in the liquid phase). Beyond $\mathrm{p}_{\mathrm{CO}}$ of 0.5 atm carboxydotrophic activity declined and there was a significant lag phase prior to CO consumption (Figure 2B). The methanogenic activity from $\mathrm{CO}$ evolved differently, being at a maximum (around $1 \mathrm{mmol} / \mathrm{g}$ VSS.d) up to a $\mathrm{p}_{\mathrm{CO}}$ of $0.2 \mathrm{~atm}$ $(0.17 \mathrm{mM})$. Then the methane production rate decreased with the increase in $\mathrm{CO}$ concentration, until it was totally blocked at a $\mathrm{PCO}$ of 1 atm $(0.87 \mathrm{mM})$.

Methane, acetate, propionate, and $\mathrm{H}_{2}$ were the main products of the CO conversion, and their yield varied depending on the initial $\mathrm{CO}$ concentration (Table 1). High concentrations of $\mathrm{CO}$ clearly affect the $\mathrm{CH}_{4}$ yield as has been reported in previous studies with anaerobic sludge and pure cultures 


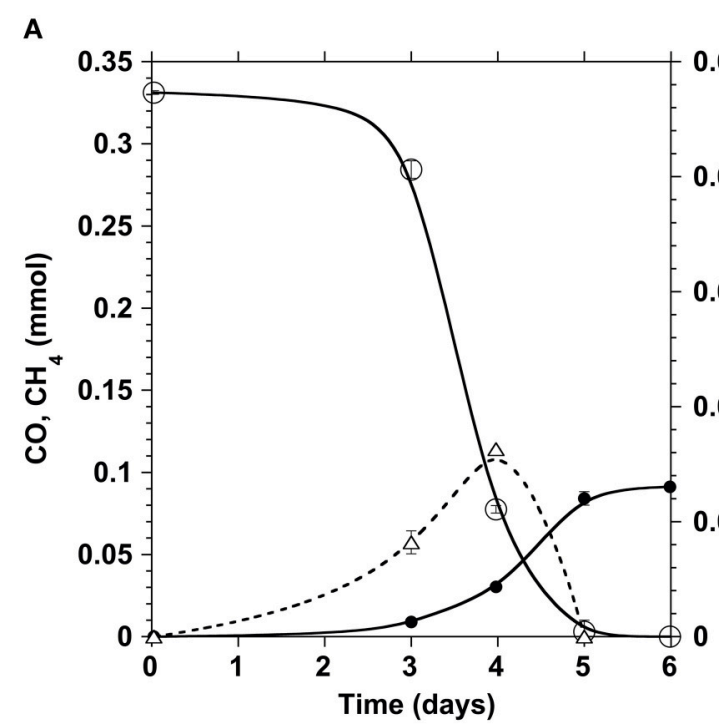

\section{B}

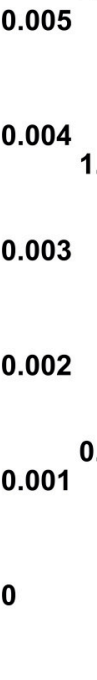

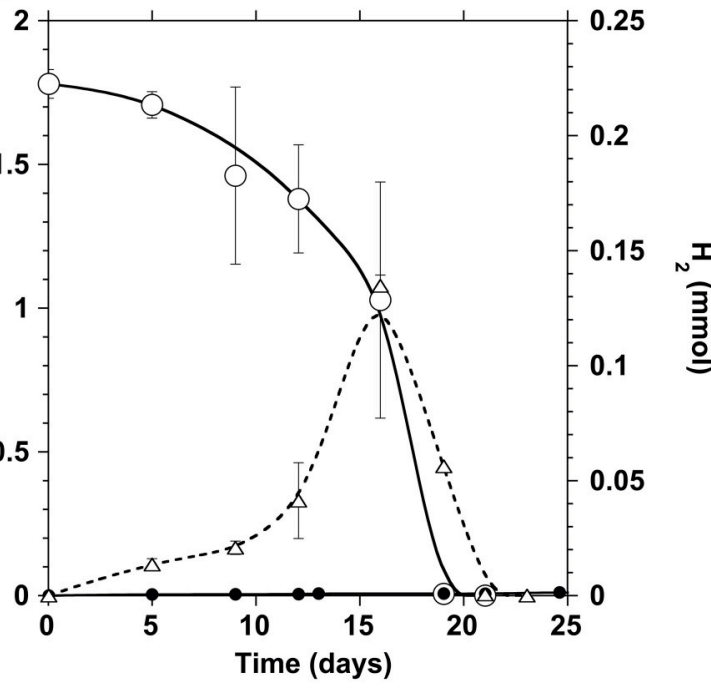

FIGURE 2 | Time courses of $\mathrm{CO}$ (open circles), $\mathrm{CH}_{4}$ (filled circles), and $\mathrm{H}_{2}$ (triangles) in the incubation bottles at a $\mathrm{p}$ CO of 0.2 (A) and $1 \mathrm{~atm}$ (B). The ordinate values refer to the whole gas content of test bottles.

TABLE 1 | Carboxydotrophic and methanogenic activities and product yields of the disaggregated anaerobic sludge granules as a function of the CO concentration in the liquid phase at $35^{\circ} \mathrm{C}$.

\begin{tabular}{|c|c|c|c|c|c|c|c|}
\hline \multirow[t]{2}{*}{$\begin{array}{l}\text { CO initial content } \mathrm{mmol} / \mathrm{L}^{*} \\
\left(\mathrm{p}_{\mathrm{co}}, \text { atm }\right)\end{array}$} & \multirow[t]{2}{*}{$t_{\max ^{* \star}}(\mathrm{d})$} & \multirow[t]{2}{*}{$\begin{array}{l}\text { CO specific activity } \\
\text { (mmol CO/g VSS.d) }\end{array}$} & \multirow[t]{2}{*}{$\begin{array}{l}\mathrm{CH}_{4} \text { specific activity } \\
\text { (mmol } \mathrm{CH}_{4} / \mathrm{g} \text { VSS.d) }\end{array}$} & \multicolumn{3}{|c|}{$\begin{array}{c}\text { Products formed } \\
(\% \text { of the stoichiometric yield })^{\ddagger}\end{array}$} & \multirow[t]{2}{*}{$\begin{array}{l}\mathrm{H}_{2} \text { at maximum } \\
\quad\left(\text { atm. } 10^{-3}\right)\end{array}$} \\
\hline & & & & $\mathrm{CH}_{4}$ & Acetate & Propionate & \\
\hline $0.09(0.10)$ & 4 & $1.77 \pm 0.20$ & $1.17 \pm 0.15$ & $132 \pm 2$ & $9 \pm 7$ & $21 \pm 22$ & $0.5 \pm 0.06$ \\
\hline $0.17(0.20)$ & 3 & $5.37 \pm 0.26$ & $0.99 \pm 0.02$ & $95 \pm 5$ & $5 \pm 3$ & $7 \pm 0.3$ & $1.1 \pm 0.02$ \\
\hline $0.26(0.30)$ & 5 & $7.13 \pm 1.27$ & $0.54 \pm 0.02$ & $62 \pm 38$ & $38 \pm 18$ & $9 \pm 0.2$ & $2.4 \pm 2.8$ \\
\hline 0.87 (1.0) & 14 & $7.65 \pm 1.12$ & $0.05 \pm 0.03$ & $2 \pm 0.5$ & $46 \pm 18$ & $21 \pm 9$ & $56 \pm 13$ \\
\hline $1.31(1.5)$ & 37 & $7.09 \pm 0.57$ & $0.00 \pm 0.00$ & $0.5 \pm 0.1$ & $33 \pm 24$ & $15 \pm 12$ & $50 \pm 5$ \\
\hline
\end{tabular}

${ }^{*}$ Dissolved CO concentrations from 0.09 to $1.31 \mathrm{mmol} / \mathrm{L}$, are calculated using a value of $1148 \mathrm{~atm} \cdot \mathrm{L} / \mathrm{mol}$ for the Henry constant at $35^{\circ} \mathrm{C}$ (Zhao et al., 2013).

**Time to reach maximum activity.

${ }^{\ddagger}$ Stoichiometric yields: $1 / 4 \mathrm{~mol}$ of $\mathrm{CH}_{4}$ per mol $\mathrm{CO}$ (reaction 1 or 5); $1 / 4$ mol of acetate per mol $\mathrm{CO}$ (reaction 4a); $1 / 7 \mathrm{~mol}$ of propionate per mol $\mathrm{CO}$ (reaction 9).

(Sipma et al., 2003; Oelgeschläger and Rother, 2008, 2009). When methanogenesis starts to decrease, the methane precursors (acetate, propionate and $\mathrm{H}_{2}$ ) begin to accumulate, proportionally to the increase of dissolved $\mathrm{CO}$ concentration. Both acetogenesis and hydrogenogenesis were still present at concentrations of $1.31 \mathrm{mmol} \mathrm{CO} / \mathrm{L}$ ( $p_{C O} 1.5 \mathrm{~atm}$ ), although their product yield started to decline at $\mathrm{CO}$ concentrations higher than $0.87 \mathrm{mmol}$ $\mathrm{CO} / \mathrm{L}$ ( $\left.\mathrm{p}_{\mathrm{CO}} 1 \mathrm{~atm}\right)$.

The optimal conditions observed for $\mathrm{CO}$ conversion at a $\mathrm{PCO}$ of $0.5 \mathrm{~atm}$ in the headspace and higher with the disaggregated sludge significantly differed from previously reported results obtained on integral sludge granules (Guiot et al., 2011). These authors reported a maximum $\mathrm{CO}$ consumption rate of $8.1 \mathrm{mmol}$ $\mathrm{CO} / \mathrm{g}$ VSS.d at $0.2 \mathrm{~atm} \mathrm{CO}$ initial partial pressure $(0.17 \mathrm{mM})$, and above this value the activity dropped drastically to $2-3 \mathrm{mmol}$ $\mathrm{CO} / \mathrm{g}$ VSS d. This discrepancy of the results between the present study, performed on disaggregated granular sludge, and previous results obtained with aggregated granular sludge, led us to question the effect of the sludge structure on carboxydotrophic activity and metabolic pathways. Further analysis was therefore conducted through activity tests using aggregated sludge granules from the current study under the same conditions as discussed above, to describe more precisely the impact of the sludge morphology on CO conversion.

The experimental results obtained followed the same pattern for the CO conversion (Figure 3). The carboxydotrophic activity increased with the amounts of $\mathrm{CO}$ supplied reaching a maximum of $6.9 \mathrm{mmol} \mathrm{CO} / \mathrm{g}$ VSS.d at a partial pressure of 0.5 atm $\mathrm{CO}$ in the gas phase $(0.44 \mathrm{mM})$. In general the $\mathrm{CO}$ consumption rate in granular morphology was slightly slower than in the disaggregated granules, which might be explained by the lower $\mathrm{CO}$ and metabolic intermediates diffusion within 


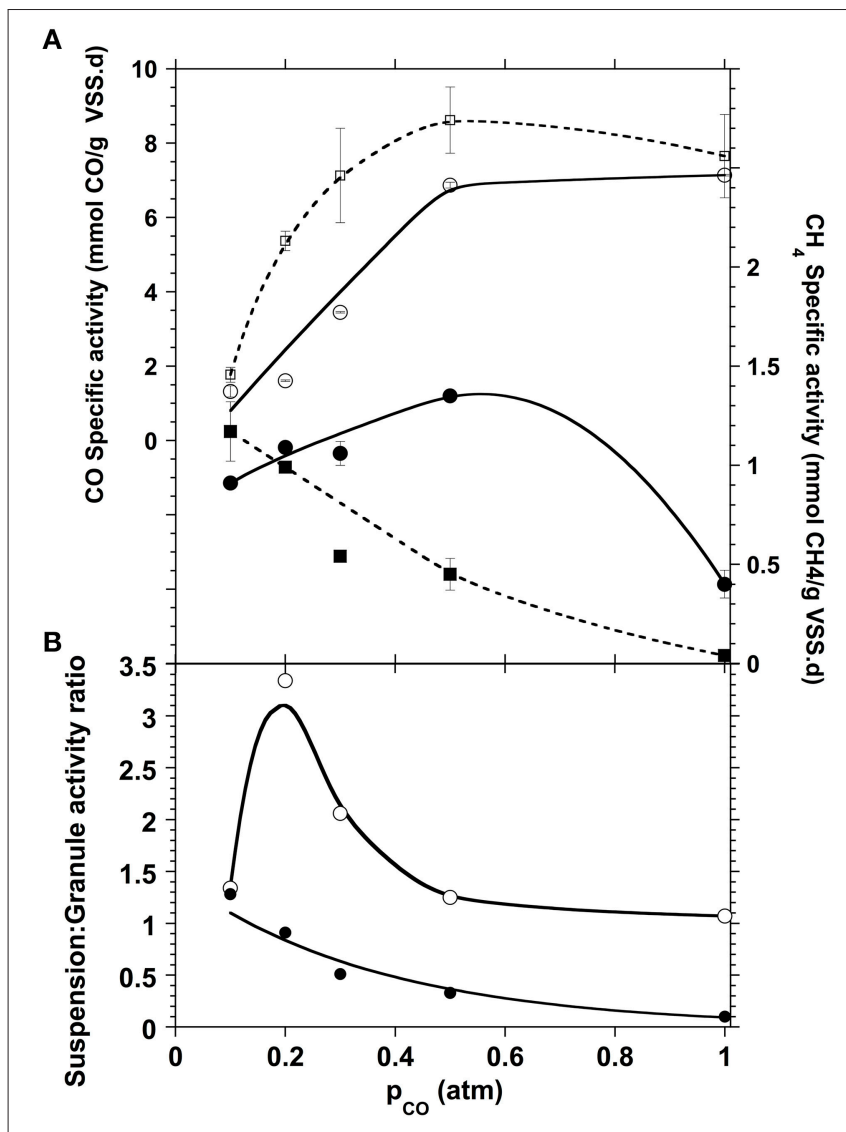

FIGURE 3 | (A) Carboxydotrophic (open symbols) and methanogenic (filled symbols) specific activities compared for both disaggregated (squares, dotted lines) and granular (circles, solid lines) sludge morphologies. (B) Activity ratio of disaggregated sludge suspension over whole granules for both carboxydotrophic (open circles) and methanogenic (black circles) specific activities.

granules and respectively, the lower substrate availability for the carboxydotrophic microorganisms present within the granule inner layers. The methane production pattern also differed depending on the morphology of the sludge. With the whole sludge granules, the methane production reached a maximum rate of $1.15 \mathrm{mmol} \mathrm{CH}_{4} / \mathrm{g}$ VSS.d at a $\mathrm{p}_{\mathrm{CO}}$ of $0.5 \mathrm{~atm}(0.44 \mathrm{mM})$, before to decrease at higher partial pressure, while that of the disaggregated sludge suspension started to decrease at a pCO as low as 0.2 atm (Figure 3). Moreover, even if the methane yield decreased with the increase of the $\mathrm{CO}$ concentration independently of the sludge morphology, this decrease was more pronounced with the disaggregated sludge. When the PCO increased from 0.2 to 1 atm the $\mathrm{CH}_{4}$ yield of the disaggregated granules decreased from the stoichiometric maximum to $2 \%$, compared to the methane yield of whole granules, which decreased to $12 \%$.

This negative impact that the disruption of the granule had on methanogenic activities is likely due to the protection that the granule offers to the methanogens. This is related to the layered distribution of the different trophic groups in the granular consortium, as reported in many studies (Guiot et al., 1992; Fang et al., 1994; Hwu et al., 1996; Sekiguchi et al., 1999; Fang, 2000; Diaz et al., 2006). The methanogens that are mostly in the core of the granule are then protected against toxic $\mathrm{CO}$ concentrations, allowing the maintenance of the methanogenic potential. Such a morphology also allows for a closer juxtaposition between the different trophic groups of microorganisms that participate in the $\mathrm{CO}$ conversion to $\mathrm{CH}_{4}$, hence enhancing the flux of metabolites between their producers and consumers.

\section{CO Conversion Routes}

The major metabolites of $\mathrm{CO}$ conversion are $\mathrm{CH}_{4}$ and acetate, however the presence of hydrogen, and propionate is also noted in the microcosms. These observations suggest that acetate is the main methane precursor. However, to determine the possible routes of methane formation it is essential to discriminate between a direct conversion of $\mathrm{CO}$ to methane and an indirect conversion via acetate, and/or $\mathrm{H}_{2}$ and $\mathrm{CO}_{2}$ (or formate). In order to understand this, specific inhibitors for bacteria and archaea (methanogens) were used. The use of vancomycin as acetogenic inhibitor allows the evaluation of direct and/or hydrogenotrophic pathway through methane formation. BES generally blocks methanogenesis, while FA inhibits acetate consumption by acetoclastic methanogenic archaea and acetate-oxidizing bacteria (Figure 1). A first series of tests were made at $0.2 \mathrm{~atm} \mathrm{CO}$ partial pressure in the headspace $(0.17 \mathrm{mM})$ corresponding to the optimal methanogenic activity in the sludge studied. The specific activity results are displayed in Table 2 , and the time courses for $\mathrm{CO}, \mathrm{CH}_{4}$, and $\mathrm{H}_{2}$ are shown in Figures $2 \mathrm{~A}, 4$ (top). In presence of vancomycin $\mathrm{CO}$ conversion rates were very low compared to the uninhibited one, but the entire $\mathrm{CO}$ was converted to methane, and little volatile acids were observed. In presence of BES the carboxydotrophic activity was reduced approximately by half (from 5.37 to $2.39 \mathrm{mmol} \mathrm{CO} / \mathrm{g} \mathrm{VSS} . \mathrm{d}$ ), and led to the accumulation of acetate, propionate, and hydrogen as final products from CO. This decrease in carboxydotrophic activity when methanogenesis is blocked does not mean that direct carboxydotrophic methanogenesis is a significant pathway since the rate of CO conversion to methane in presence of vancomycin was a small fraction of that in the control test. Nonetheless, based on the data obtained with vancomycin tests, one possible explanation for the decrease in the CO conversion rate could be the feedback inhibitory effect by the accumulated products from $\mathrm{CO}$ (i.e., acetate and/or $\mathrm{H}_{2}$ ) when methanogenesis is blocked. This scenario of substrate conversion inhibition by the accumulated products has been described earlier by various authors working with anaerobic consortia (Yu and Pinder, 1993; Schulz and Conrad, 1996). In absence of methanogenesis acetate was the metabolite with the highest accumulation at all the CO concentrations tested, which lead us to assume that the partial pressure of CO didn't have any effect on the metabolic pathways involved in methane production, and acetate was the main intermediate. In presence of fluoroacetate (FA) the CO conversion rate was further reduced to $29 \%$ of that without inhibitors (from 5.37 to $1.57 \mathrm{mmol} \mathrm{CO/g} \mathrm{VSS.d),} \mathrm{and} \mathrm{to} 66 \%$ of the rate attained in the presence of BES, and neither $\mathrm{H}_{2}$ nor propionate was detected at the end of the test. Only $29 \%$ of the CO was converted to acetate (possibly due to feedback 
TABLE 2 | Carboxydotrophic and methanogenic activities and product yields of the disaggregated anaerobic sludge granules under a CO pressure in the gas phase of $0.2 \mathrm{~atm}(0.17 \mathrm{mM}$ in the liquid phase) and inhibitory effect of 2-bromo-ethane sulfonate (BES) (50 $\mathrm{mM})$, vancomycin ( $0.07 \mathrm{mM})$, and fluoroacetate $(5 \mathrm{mM})$ at $35^{\circ} \mathrm{C}$.

\begin{tabular}{|c|c|c|c|c|c|c|c|}
\hline \multirow[t]{2}{*}{ Inhibitor } & \multirow[t]{2}{*}{$t_{\max }{ }^{*}(d)$} & \multirow[t]{2}{*}{$\begin{array}{l}\text { CO specific activity } \\
\text { (mmol CO/g VSS.d) }\end{array}$} & \multirow[t]{2}{*}{$\begin{array}{l}\mathrm{CH}_{4} \text { specific activity } \\
\text { (mmol } \mathrm{CH}_{4} / \mathrm{g} \text { VSS.d) }\end{array}$} & \multicolumn{3}{|c|}{$\begin{array}{c}\text { Products formed } \\
(\% \text { of the stoichiometric yield })^{\ddagger}\end{array}$} & \multirow[t]{2}{*}{$\begin{array}{c}\mathrm{H}_{2} \text { at maximum } \\
\left(\text { atm. } 10^{-3}\right)\end{array}$} \\
\hline & & & & $\mathrm{CH}_{4}$ & Acetate & Propionate & \\
\hline- & 3 & $5.37 \pm 0.26$ & $0.99 \pm 0.02$ & $95 \pm 5$ & $5 \pm 3$ & $7 \pm 0.3$ & $1.1 \pm 0.02$ \\
\hline Vancomycin & $\star \star$ & $0.36 \pm 0.05$ & $0.14 \pm 0.01$ & $130 \pm 4$ & $21 \pm 15$ & $7 \pm 0.4$ & $0.3 \pm 0.01$ \\
\hline BES & 4 & $2.39 \pm 0.46$ & $0.01 \pm 0.00$ & $9 \pm 0.3$ & $51 \pm 8$ & $17 \pm 0.0$ & $5.6 \pm 2.3$ \\
\hline Fluoroacetate & 3 & $1.57 \pm 0.27$ & $0.33 \pm 0.04$ & $61 \pm 5$ & $29 \pm 0.8$ & 0 & $0.9 \pm 0.2$ \\
\hline
\end{tabular}

*Time to reach maximum activity.

**The activity rate did not change for the experiment duration.

${ }^{\ddagger}$ Stoichiometric yields: ${ }^{1} 1 / 4 \mathrm{~mol}$ of $\mathrm{CH}_{4}$ per mol CO (reaction 1 or 5); $1 / 4$ mol of acetate per mol CO (reaction 4 a); $1 / 7 \mathrm{~mol}$ of propionate per mol CO (reaction 9).

inhibition). It is noteworthy that the methane yield remained relatively high, at $61 \%$ of the stoichiometric yield, even though the acetoclastic activity was inhibited. Consequently the methane produced was coming from a different source (i.a. $\mathrm{H}_{2} / \mathrm{CO}_{2}$ ).

In presence of vancomycin the $\mathrm{CO}$ conversion rates observed with all the $\mathrm{CO}$ concentrations tested were very low compared to the uninhibited ones (Table 3). Typical time courses of the CO depletion and the hydrogen and methane production at a $1 \mathrm{~atm}$ pCO are shown in Figures 2B, 4 (bottom). The lag time preceding the $\mathrm{CO}$ depletion increased in presence of BES, and even more in presence of vancomycin. Generally in absence of active acetogens only a fraction of the carboxydotrophic activity was expressed (between 7 and 30\%). The maximum rate $(2.11 \mathrm{mmol} \mathrm{CO} / \mathrm{g}$ VSS.d) was achieved at $1 \mathrm{~atm}$ CO partial pressure $(0.87 \mathrm{mM})$, which represented only $30 \%$ of the CO conversion rate of the test without inhibitor. These data suggest that direct $\mathrm{CO}$ conversion to methane or via $\mathrm{H}_{2} / \mathrm{CO}_{2}$ (or formate) as intermediates were not important pathways in the studied sludge. Moreover as opposed to the uninhibited test, when acetogenic bacteria were inhibited in presence of vancomycin the methanogenic activity in the sludge increased with the amount of $\mathrm{CO}$ applied, with a peak of $0.74 \pm 0.06 \mathrm{mmol} \mathrm{CH}_{4} / \mathrm{g}$ VSS.d at $1 \mathrm{~atm}$ pCO, which is not far from the maximum methanogenic activity observed without inhibitor.

In presence of vancomycin at low $\mathrm{p}_{\mathrm{CO}}$, the methane yield was significantly higher than the stoichiometric (i.e., maximal) yield (Table 3, pco $0.1-0.3 \mathrm{~atm}$ ). This was probably due to the degradation of organic matter brought with inoculation (cell lysis products, microbial secretions, extracellular polymeric substances) (Zhang and Bishop, 2003). The products of that organic matter's fermentation by the vancomycin resistant gram-negative bacteria might afterwards be transformed into $\mathrm{CH}_{4}$ thus increasing the observed yield. This contribution is likely weightier under substrate-limiting conditions. This was confirmed with endogenous tests (no substrate) and vancomycin. However, at a $1 \mathrm{~atm}$ p $\mathrm{CO}$ or above, even though the methane production rate was higher than at lower $\mathrm{p}_{\mathrm{CO}}$, the methane yield from $\mathrm{CO}$ decreased, and $\mathrm{H}_{2}$ started to accumulate. This observation is consistent with previous work with $M$. barkeri growing on $\mathrm{CO}$ as the sole carbon and energy source (O'Brien et al., 1984). In the study $\mathrm{H}_{2}$ formation occurred at $\mathrm{p}_{\mathrm{CO}}$ higher than 0.2 atm in the gas phase, but methane was the main metabolite at $\mathrm{CO}$ concentrations below this value. In another study with M. acetivorans (Oelgeschläger and Rother, 2009) the authors discuss that the methane formation rate is not inhibited at high $\mathrm{CO}$ concentrations, but the increase in $\mathrm{CO}$ partial pressure also leads to the rate increase of other products formed from $\mathrm{CO}$, which could cause a decrease in the final amount of $\mathrm{CO}$ converted to methane.

In presence of $\mathrm{BES}$, at all $\mathrm{CO}$ concentrations above 0.1 $\mathrm{mM}$, the carboxydotrophic activity was reduced to two- to one-third of that obtained without inhibitor. The inhibition of methanogenesis by BES led to the accumulation of acetate, propionate and hydrogen as final products from CO. Acetate was the metabolite with the highest accumulation at all the $\mathrm{CO}$ concentrations tested, which confirms that acetate is the main intermediate of the CO transformation into methane. Therefore both methanogenic pathways, via $\mathrm{H}_{2} / \mathrm{CO}_{2}$ (and/or formate) and via acetate, seem to be co-existing if hydrogenogenic bacteria and hydrogenotrophic methanogens are present in the consortium. However, as previously reported (Sancho Navarro et al., 2014), acetoclastic methanogenesis seems to be the dominant pathway when the conditions are favorable for methanogenesis to happen, instead of the direct carboxydotrophic methanogenesis route.

\section{Effect of Long Term Exposure to CO}

Since the methane production rate observed in the vancomycin assays tend to increase at higher CO concentrations, together with the lag time required for the carboxydotrophic activity to be achieved, this suggests that adaptation of the microbial populations present in the sludge can occur over time due to exposure to the high $\mathrm{CO}$ concentrations. To evaluate this hypothesis, activity tests under a fixed 100\% CO atmosphere in the gas phase were performed over 45 days. The carboxydotrophic activity and methane potential achieved over time are presented in Table 4. There is a clear correlation between the exposure time to $\mathrm{CO}$ and the methanogenic potential in the consortium. Both the carboxydotrophic and methanogenic activity increased drastically between day 30 and 45 of incubation, achieving a maximum methane production rate of $5.5 \pm 1.2 \mathrm{mmol} \mathrm{CH}_{4} / \mathrm{g}$ VSS.d at day 45 . After such an acclimation of the sludge it was possible to reach a yield of $90 \%$ 


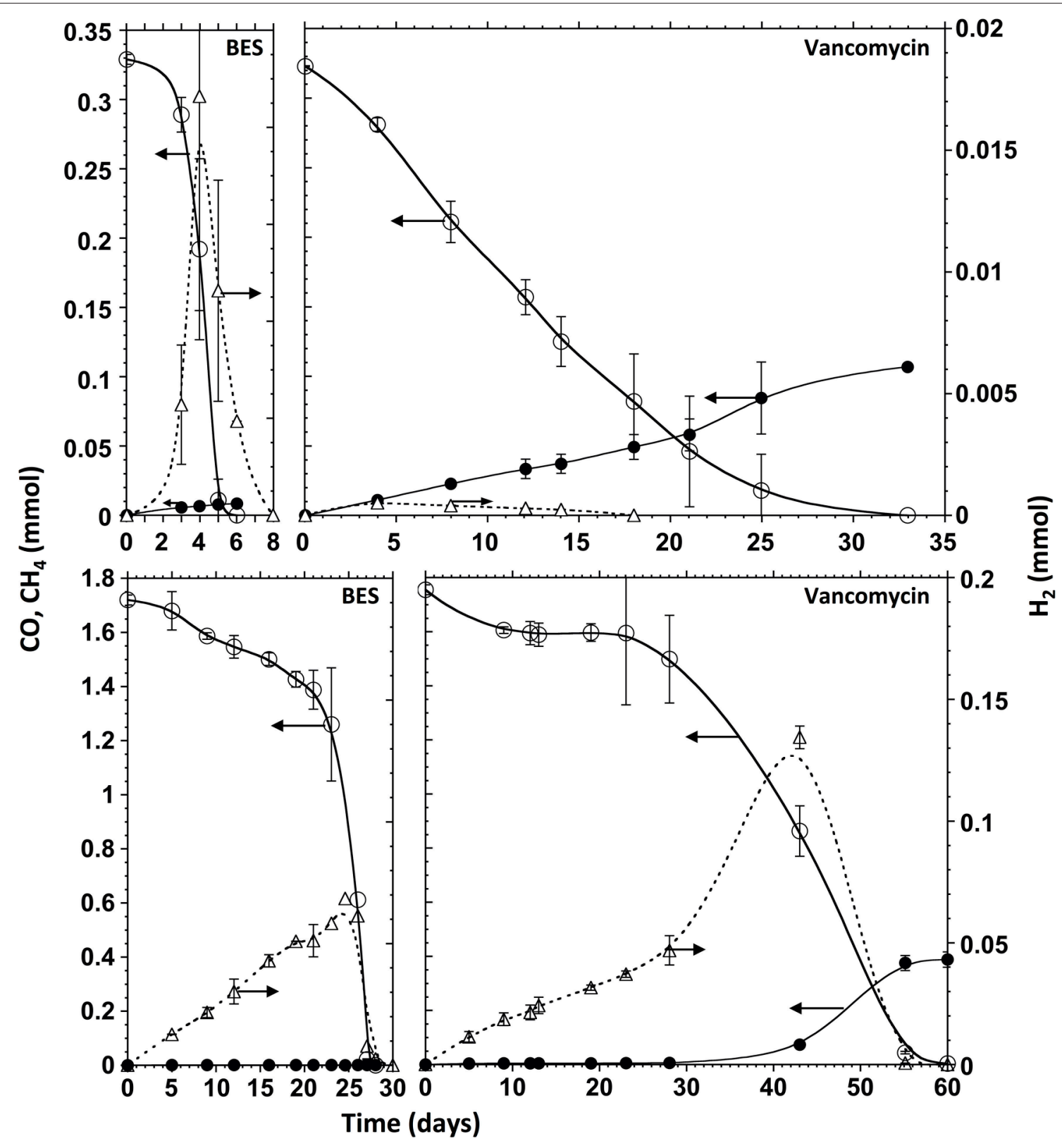

FIGURE 4 | Time courses of $\mathrm{CO}$ (open circles, solid line), $\mathrm{CH}_{\mathbf{4}}$ (filled circles, solid line) and $\mathrm{H}_{2}$ (triangles, dotted line) in presence of $\mathrm{BES}$ (left panels), and vancomycin (right panels), at $\mathbf{0 . 2}$ atm of $\mathbf{C O}$ (upper panels) and $\mathbf{1}$ atm of $\mathbf{C O}$ (lower panels) in the headspace. The ordinate values refer to the whole gas content of test bottles.

at a $\mathrm{PCO}$ of $1 \mathrm{~atm}$, whereas without acclimation, this yield was only $8 \%$ for the same CO pressure conditions.

To examine the possible variation in the microbial population over the time due to such an adaptation to a $100 \%$ CO atmosphere, DGGE experiments were performed in parallel to the activity tests. Sludge was sampled after an incubation of 30 and 45 days. The bacterial and archaeal 16S rDNA sequences of interest were compared either to the GenBank database by using BLAST or to the Ribosomal Database Project (RDP) 16S rDNA database by using the RDP classifier platform. Phylogenetic affiliations determined by BLAST and RDP classifier for the selected bacterial and archaeal 16S rDNA sequences are presented in Table 5. The results confirmed a shift in both the bacterial and the archaeal populations, corresponding to the increased methanogenic potential observed at 45 days of incubation. Clostridium propionicum, a propionate producing bacterium (Johns, 1952), and Acetobacterium wieringae, an acetate producing bacterium (Braun and Gottschalk, 1982), which were not detected at the beginning of the test, appeared to be important in the bacterial population after a 
TABLE 3 | Carboxydotrophic and methanogenic activities and product yields of the disaggregated anaerobic sludge granules, under different CO initial concentrations in presence of BES $(50 \mathrm{mM})$, and vancomycin $(0.07 \mathrm{mM})$ at $35^{\circ} \mathrm{C}$.

\begin{tabular}{|c|c|c|c|c|c|c|c|c|c|}
\hline \multirow{2}{*}{$\begin{array}{l}\text { CO initial liquid } \\
\text { conc. (mM) } \\
\text { (headspace, atm) }\end{array}$} & \multirow[t]{2}{*}{$t_{\max }(d)^{*}$} & \multirow{2}{*}{$\begin{array}{c}\text { CO specific } \\
\text { activity (mmol } \\
\text { cO/g VSS.d) }\end{array}$} & \multirow{2}{*}{$\begin{array}{c}\text { Relative CO } \\
\text { conversion } \\
\text { rate }(\%)^{\S}\end{array}$} & \multirow{2}{*}{$\begin{array}{c}\mathrm{CH}_{4} \text { specific } \\
\text { activity (mmol } \\
\text { CO/g VSS.d) }\end{array}$} & \multirow{2}{*}{$\begin{array}{c}\text { Relative } \mathrm{CH}_{4} \\
\text { conversion } \\
\text { rate }(\%)^{\S}\end{array}$} & \multicolumn{3}{|c|}{$\begin{array}{c}\text { Products formed } \\
(\% \text { of the stoichiometric yield })^{\ddagger}\end{array}$} & \multirow{2}{*}{$\begin{array}{c}\mathrm{H}_{2} \text { at } \\
\text { maximum } \\
\left(\operatorname{atm} \cdot 10^{-3}\right)\end{array}$} \\
\hline & & & & & & $\mathrm{CH}_{4}$ & Acetate & Propionate & \\
\hline \multicolumn{10}{|l|}{ VANCOMYCIN } \\
\hline $0.09(0.1)$ & $\star \star$ & $0.26 \pm 0.03$ & $15 \pm 2$ & $0.15 \pm 0.03$ & $13 \pm 3$ & $154 \pm 6$ & $13 \pm 3$ & $30 \pm 10$ & $0.4 \pm 0.01$ \\
\hline $0.17(0.2)$ & ** & $0.36 \pm 0.05$ & $7 \pm 1$ & $0.14 \pm 0.01$ & $14 \pm 1$ & $130 \pm 4$ & $21 \pm 15$ & $17 \pm 0.0$ & $0.3 \pm 0.01$ \\
\hline $0.26(0.3)$ & 20 & $0.53 \pm 0.08$ & $7 \pm 1$ & $0.17 \pm 0.0$ & 31 & $113 \pm 3$ & $3 \pm 1$ & $12 \pm 0$ & $0.4 \pm 0.005$ \\
\hline $0.44(0.5)$ & 44 & $0.99 \pm 0.06$ & $11 \pm 1$ & $0.26 \pm 0.04$ & $58 \pm 18$ & $89 \pm 8$ & 8 & 7 & $1.2 \pm 0.2$ \\
\hline $0.87(1.0)$ & 40 & $2.11 \pm 0.32$ & $30 \pm 5$ & $0.74 \pm 0.06$ & $1480 \pm 60$ & $89 \pm 0.2$ & 2.6 & 3.5 & 85 \\
\hline $1.31(1.5)$ & 55 & $1.38 \pm 0.05$ & $19 \pm 1$ & $0.31 \pm 0.06$ & $\infty$ & $66 \pm 22$ & $7 \pm 0.1$ & $5.4 \pm 1.9$ & $72 \pm 1.2$ \\
\hline \multicolumn{10}{|l|}{ BES } \\
\hline $0.09(0.1)$ & 5 & $2.10 \pm 0.14$ & $119 \pm 8$ & $0.05 \pm 0.0$ & 4 & $28 \pm 0.2$ & $67 \pm 2$ & $18 \pm 3$ & $3.3 \pm 0.01$ \\
\hline $0.17(0.2)$ & 4 & $2.39 \pm 0.46$ & $45 \pm 9$ & $0.01 \pm 0.0$ & 1 & $9 \pm 0.3$ & $51 \pm 8$ & $7 \pm 0.4$ & $5.6 \pm 2.3$ \\
\hline $0.26(0.3)$ & 5 & $2.14 \pm 0.11$ & $30 \pm 2$ & $0.03 \pm 0.01$ & $6 \pm 2$ & $12 \pm 3$ & $82 \pm 4$ & $17 \pm 1$ & $28 \pm 14$ \\
\hline $0.44(0.5)$ & 8 & $4.64 \pm 0.30$ & $54 \pm 3$ & $0.00 \pm 0.0$ & 0 & $2 \pm 0$ & $54 \pm 3$ & $10 \pm 1$ & $22 \pm 5$ \\
\hline $0.87(1.0)$ & 21 & $6.30 \pm 0.28$ & $82 \pm 12$ & $0.001 \pm 0.00$ & 2 & $0.4 \pm 0.0$ & $57 \pm 14$ & $16 \pm 8$ & $37 \pm 5$ \\
\hline $1.31(1.5)$ & 31 & $2.92 \pm 0.61$ & $41 \pm 9$ & $0.000 \pm 0.00$ & 0 & $0.1 \pm 0.1$ & $45 \pm 7$ & $11 \pm 1$ & $37 \pm 12$ \\
\hline
\end{tabular}

*Time to reach maximum activity.

** The activity rate did not change over the experiment interval.

\$The relative conversion rates are calculated as the percentage of the average rate in the control assays (without inhibitor, Table 1).

${ }^{\ddagger}$ Stoichiometric yields: ${ }^{1} / 4 \mathrm{~mol} \mathrm{CH} 4$ per mol CO (reaction 1 or 5); $11 / 4$ mol acetate per mol CO (reaction 4a); $1 / 7$ mol propionate per mol CO (reaction 9).

TABLE 4 | Change in the carboxydotrophic and methanogenic rate potential of the disaggregated anaerobic sludge granules, under a CO $100 \%$ atmosphere in the gas phase, as a function of the adaptation time.

\begin{tabular}{|c|c|c|c|c|c|c|}
\hline $\begin{array}{l}\text { Time } \\
\text { days }\end{array}$ & $\begin{array}{c}\text { CO specific } \\
\text { activity mmol } \\
\text { co/g VSS.d }\end{array}$ & $\begin{array}{l}\mathrm{CH}_{4} \text { specific } \\
\text { activity mmol } \\
\mathrm{CH}_{4} / \mathrm{g} \text { VSS.d }\end{array}$ & $\begin{array}{c}\mathrm{CH}_{4} \text { yield } \\
\text { stoichiometric } \\
\%^{\ddagger}\end{array}$ & $\begin{array}{c}\text { Acetate yield } \\
\text { stoichiometric } \\
\%^{\ddagger}\end{array}$ & $\begin{array}{c}\text { Accumulated } \\
\text { acetate } \\
\text { concentration } \mathrm{mM}\end{array}$ & $\begin{array}{l}\text { Max. } \mathrm{p}_{\mathrm{H} 2} \\
\text { atm.10-3 }\end{array}$ \\
\hline 0 & $8.5 \pm 2.7$ & $0.04 \pm 0$ & $7.8 \pm 0.63$ & $10.3 \pm 4.1$ & 0.18 & $56 \pm 13$ \\
\hline 30 & $11.7 \pm 1.6$ & $0.7 \pm 1.3$ & $23.0 \pm 44.5$ & - & - & $152 \pm 25$ \\
\hline 45 & $24.2 \pm 5.9$ & $5.5 \pm 1.2$ & $90.4 \pm 29.6$ & $3.2 \pm 0.4$ & 17 & $43 \pm 15$ \\
\hline
\end{tabular}

${ }^{\ddagger}$ Stoichiometric yields: ${ }^{1} / 4 \mathrm{~mol}$ of $\mathrm{CH}_{4}$ per mol CO (reaction 1 or 5$) ; 1 / 4 \mathrm{~mol}$ of acetate per mol CO (reaction 4 a).

month of incubation at high $\mathrm{CO}$ concentrations, suggesting that high $\mathrm{p}_{\mathrm{CO}}$ conditions positively stimulated their growth. This increase in the abundance of these two species in the microbial community corresponded to the previously observed acetate and propionate accumulation at high $\mathrm{CO}$ concentrations in the activity tests. In addition to those two bacteria, Petrimonas sulfuriphila, a fermentative acetate and $\mathrm{H}_{2} / \mathrm{CO}_{2}$ producer (Grabowski et al., 2005), and Geobacter uraniireducens sp., a SAO bacterium (Shelobolina et al., 2008), were detected after 30 or 45 days of CO exposure. Variations in the archaeal population were also observed, with notably a shift toward a dominance of hydrogen-utilizing methanogens over time. Microorganisms belonging to the orders Methanomicrobiales and Methanobacteriales were found to be present in the consortium after 30 or 45 days of CO exposure, suggesting a better adaptation of those populations to high $\mathrm{CO}$ concentrations.

\section{DISCUSSION}

Based on the data obtained with the specific inhibitors we assumed that methane production from $\mathrm{CO}$ was mainly via acetate as an intermediate metabolite, as previously observed (O'Brien et al., 1984; Sipma et al., 2003; Sancho Navarro et al., 2014). This was further confirmed by the dominance of Methanosaeta species in the microbial population, even though the hydrogenotrophic methanogenesis was also present and significant in the sludge examined.

When methanogens were inhibited in presence of BES, acetate was the major metabolite accumulated in all the $\mathrm{CO}$ concentrations tested, although $\mathrm{H}_{2}$ and propionate were also present but to a lesser extent. In the absence of an inhibitor these metabolites were completely converted to methane under optimal methanogenic conditions ( $0.2 \mathrm{~atm}$ pCO), but started to accumulate at higher $\mathrm{CO}$ concentrations, due to the 
TABLE 5 | Evolution of the eubacterial and archaeal populations in the anaerobic sludge over the adaptation time, under an atmosphere of $100 \%$ CO as determined by DGGE experiments.

\begin{tabular}{|c|c|c|c|c|c|}
\hline \multirow[t]{2}{*}{$\begin{array}{l}\text { Identified Microorganism (GenBank } \\
\text { Accession Number) }\end{array}$} & \multirow[t]{2}{*}{$\begin{array}{l}\% \text { Similarity (Sequence } \\
\text { Length) }\end{array}$} & \multicolumn{3}{|c|}{$\begin{array}{l}\text { Presence }(+) \text { or absence }(-) \text { of the } \\
\text { microorganism in the population }\end{array}$} & \multirow[t]{2}{*}{$\begin{array}{l}\text { RDP Classifier } \\
\text { Classification }\end{array}$} \\
\hline & & Day 0 & Day 30 & Day 45 & \\
\hline \multicolumn{6}{|l|}{ EUBACTERIA } \\
\hline $\begin{array}{l}\text { Clostridium propionicum, strain: JCM } \\
1430 \text { (AB649276.1) }\end{array}$ & $100 \%(400 / 400)$ & - & + & + & Clostridium XIVb (100\%) \\
\hline $\begin{array}{l}\text { Acetobacterium wieringae, strain: DP9 } \\
(\mathrm{HQ} 384240.1)\end{array}$ & 99\% (394/396) & - & + & + & Acetobacterium (100\%) \\
\hline $\begin{array}{l}\text { Uncultured Bacteroidetes bacterium, } \\
\text { clone: L D1 16S (HQ003602.1) }\end{array}$ & $99 \%(357 / 391)$ & - & - & + & Bacteroidetes (99\%) \\
\hline $\begin{array}{l}\text { Petrimonas sulfuriphila, strain: BN3 } \\
\text { (NR042987.1) }\end{array}$ & $94 \%(391 / 415)$ & - & - & + & Bacteroidales (100\%), Petrimonas (96\%) \\
\hline $\begin{array}{l}\text { Geobacter uraniireducens Rf4 } \\
\text { (CP000698.1) }\end{array}$ & $97 \%(399 / 411)$ & - & + & + & $\begin{array}{l}\text { Desulfuromonadales (100\%), Geobacteraceae } \\
(97 \%), \text { Geobacter (94\%) }\end{array}$ \\
\hline $\begin{array}{l}\text { Brevundimonas bullata, strain: NBRC } \\
13290\end{array}$ & $98 \%(380 / 388)$ & - & + & - & $\begin{array}{l}\text { Alphaproteobacteria (100\%), Caulobacteraceae } \\
(99 \%), \text { Brevundimonas (97\%) }\end{array}$ \\
\hline \multicolumn{6}{|l|}{ ARCHAEA } \\
\hline $\begin{array}{l}\text { Methanosaeta concilii, strain: NBRC } \\
103675 \text { (AB679168.1) }\end{array}$ & $99 \%(429 / 434)$ & + & + & + & Methanosaeta concilii (98\%) \\
\hline $\begin{array}{l}\text { Uncultured Methanolinea sp., clone: } \\
\text { SMS-T-Pro-2 (AB479406.1) }\end{array}$ & $99 \%(431 / 433)$ & - & + & + & Methanolinea tarda (89\%) \\
\hline $\begin{array}{l}\text { Uncultured Methanobacteriaceae } \\
\text { archaeon, clone: AR-H2-B (AB236069.1) }\end{array}$ & $100 \%(429 / 429)$ & - & - & + & Methanobacterium congolense (98\%) \\
\hline
\end{tabular}

inhibitory effect that $\mathrm{CO}$ exerts on methanogenesis, as reported in previous work (Oelgeschläger and Rother, 2008, 2009). Other studies (Rother and Metcalf, 2004; Lessner et al., 2006) reported that higher exposure to $\mathrm{CO}$ leads to the apparent down-regulation of the operon mtr, which encodes for the enzyme catalyzing the methyl transfer from the $\mathrm{N}$-methyltetrahydrosarcinapterin to the coenzyme $M$, necessary in the last catabolic step before methane production during growth on $\mathrm{H}_{2} / \mathrm{CO}_{2}$ or acetate (Welander and Metcalf, 2005). Hence, at higher $\mathrm{CO}$ concentrations when the conditions are unfavorable for methanogens, hydrogen-utilizing bacteria and acetogenic bacteria may take over in the population. These results are consistent with literature, which reports many acetogens and hydrogenogens able to grow at high CO concentrations (Sipma et al., 2006; Oelgeschläger and Rother, 2008; Techtmann et al., 2009).

Methane production from $\mathrm{CO}$ via acetate as the main intermediate was further supported in presence of vancomycin when acetogenic bacteria were inhibited. The pronounced decrease in carboxydotrophic activity observed under these conditions clearly indicates that direct methane production from $\mathrm{CO}$ or indirectly via $\mathrm{H}_{2} / \mathrm{CO}_{2}$ was secondary in the sludge studied, as has been reported in previous studies (Klasson et al., 1990; Oelgeschläger and Rother, 2008; Guiot et al., 2011; Sancho Navarro et al., 2014). This can be explained by the higher energy balance of CO-utilizing acetogenic bacteria as compared to the carboxydotrophic hydrogenogens (i.e., $\Delta \mathrm{G}^{\circ \prime}=-44$ vs. $-20 \mathrm{~kJ} / \mathrm{mol} \mathrm{CO}$ ), as well as the slightly higher doubling time achieved by hydrogenogens (Henstra et al., 2007). Hence this makes acetogenic bacteria a better competitor for $\mathrm{CO}$ than hydrogenogens, the former thus becoming dominant in the population under $\mathrm{CO}$ conditions, as was shown in the molecular analyses performed over a long term exposure to $\mathrm{CO}$. On the other hand the minimal direct $\mathrm{CO}$ conversion to methane observed in the consortium might be due to the poor kinetic properties of methanogens compared to COhydrogenogenic and acetogenic bacteria. This is coherent with previous work where the authors reported a higher $\mathrm{CO}$ affinity by the carbon monoxide dehydrogenase (CODH) enzyme in carboxydotrophic hydrogenogens and acetogens than in methanogens (Oelgeschläger and Rother, 2008).

Interestingly, in the vancomycin assays where acetogenic activity was inhibited, an increase of the methanogenic activity with the amount of CO supplied was observed, in contrast to the uninhibited tests. It is hypothesized that the adaptation of methanogens through their longer exposure to CO (longer lag time) allowed for the observed increase. This hypothesis was confirmed with the tests performed under $100 \% \mathrm{CO}$, where the sludge achieved the highest methanogenic activity after 45 days of exposure to CO, and reached a $90 \%$ CO conversion to methane. Furthermore, the results obtained with the tests performed with long exposure to CO demonstrated that the sludge could achieve higher methanogenic potential under a 100\% CO atmosphere through adaptation to $\mathrm{CO}$ conditions, possibly through the regulation of the $\mathrm{CODH} /$ hydrogenase activity at the molecular level. Once sludge was adapted, $90 \%$ of the CO was converted to $\mathrm{CH}_{4}$ at the end of the experiment, whereas it was only $8 \%$ before acclimation. Previous studies with $M$. acetivorans 
A

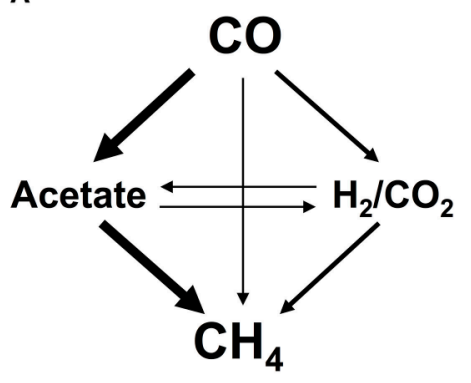

B

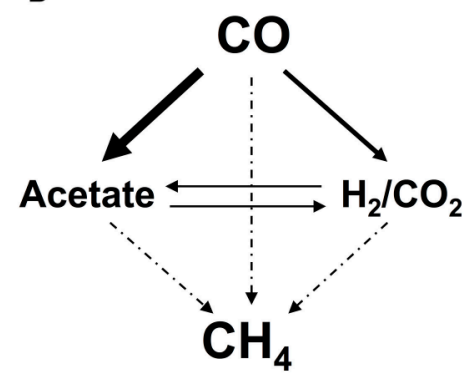

C

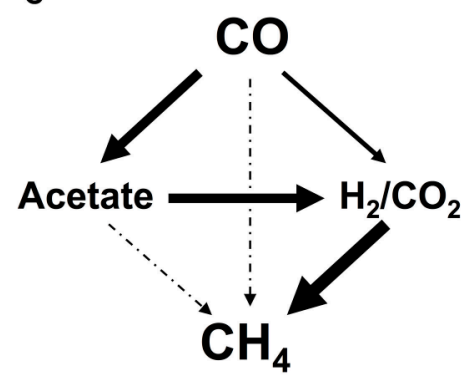

FIGURE 5 | Suggested pathways for conversion of $\mathrm{CO}$ into $\mathrm{CH}_{4}$ by a mixed anaerobic sludge, under low $\mathrm{p}_{\mathrm{CO}}\left(<0.5\right.$ atm) (A), under high $\mathrm{p}_{\mathrm{CO}}(\geq 1$ atm) (B), and after acclimation of the sludge to high CO concentrations (100\% CO in the gas phase) (C). The thickness of the arrow is representative of the relative importance of the pathway (thick, 60-80\%; intermediate, 20-40\%; thin, 5-20\%). The dotted lines indicate methane production pathways blocked by high CO concentration ( $\left.\mathrm{p}_{\mathrm{CO}} \geq 1 \mathrm{~atm}\right)$.

(Rother and Metcalf, 2004) and M. barkeri (O’Brien et al., 1984) demonstrated the microorganisms' ability to grow at $100 \% \mathrm{CO}$ in the headspace after an adaptation period by stepwise increase of the $\mathrm{CO}$ concentration, although the methane production achieved at high CO levels in the gas phase was very low in those studies. Nonetheless, a recent study reported that an isolated $M$. acetivorans strain from prolonged incubations with $\mathrm{CO}$ was capable of producing methane directly from $\mathrm{CO}$ at high rate (Kliefoth et al., 2012).

Moreover, recent work with Carboxydothermus hydrogenoformans describes the regulation of both hydrogenaselinked $\mathrm{CODH}$ and $\mathrm{CODH} / \mathrm{ACS}$ operons for efficient consumption of $\mathrm{CO}$ across a wide range of concentrations (Techtmann et al., 2011). Those authors presented that under high PCO $_{\text {CO }}$ the bacteria were able to catabolize more $\mathrm{CO}$ into energy by overexpression of the hydrogenase, while at low $\mathrm{CO}$ concentrations the $\mathrm{CO}$ is mainly used toward carbon fixation. It seems that methanogens needed a longer adaptation time to achieve methane production at high $\mathrm{CO}$ concentrations.

The molecular analyses performed in this study showed an adaptation of the microbial population of the sludge to high $\mathrm{p}_{\mathrm{CO}}$, with an evolution toward dominance of acetate producers and acetate oxidizers. The archaeal population previously dominated by acetoclastic methanogens, namely Methanosaetaceae species, evolved into a mixed culture of acetate and hydrogen-utilizing methanogens with dominance of hydrogenotrophic methanogens (Methanobacteriales and Methanomicrobiales). Several studies already reported that the decrease of Methanosaetaceae in the population, related to stressing conditions, such as high acids or ammonia levels, typically leads to the dominance of acetate-oxidizing bacteria in syntrophic cooperation with hydrogen-utilizing methanogens (Schnürer et al., 1999; Karakashev et al., 2005, 2006; Hao et al., 2011; Lü et al., 2016). In addition, other studies (Koster and Lettinga, 1984; Borja et al., 1996; Nozhevnikova et al., 2007) highlight the noticeable sensitivity of acetoclastic methanogens to different by-products in the media, including CO (Bhatnagar et al., 1987; Sipma et al., 2006).
Therefore, we can conclude that at low CO concentrations $\mathrm{CO}$ is converted mainly to acetate by acetogenic bacteria which is subsequently transformed into methane by acetoclastic methanogens (Methanosaetaceae), while at high $\mathrm{p}_{\mathrm{CO}}$ the methanogenic activity seems to be generally inhibited by the amount of CO applied, as previously discussed (Welander and Metcalf, 2005; Oelgeschläger and Rother, 2008, 2009). However, hydrogen-utilizing methanogens, also present in the mixed anaerobic culture, were more tolerant to $\mathrm{CO}$, allowing for the $\mathrm{CO}$ conversion to methane behind hydrogenogenesis, at mid $\mathrm{CO}$ concentrations ( $0.5 \mathrm{~atm} \leq \mathrm{pCO}<1 \mathrm{~atm})$. Nonetheless, it was possible to achieve methane production at high $\mathrm{p}_{\mathrm{CO}}$ ( $\geq 1$ atm) after a sufficient acclimation to CO over time, contrary to what is reported in some studies (Sipma et al., 2003; Oelgeschläger and Rother, 2008, 2009). This adaptation to high CO concentrations led to a shift in the archaeal population, resulting in the dominance of hydrogenotrophic methanogens (Methanobacteriales and Methanomicrobiales), which increased the sludge hydrogen-consuming potential and allowed for low $\mathrm{H}_{2}$ concentrations in the medium. This drove the emergence of a syntrophic acetate oxidizing (SAO) pathway, which was able to take over acetoclastic methanogenesis, and to become the main pathway for methane production through the hydrogenotrophic methanogenesis. The proposed CO conversion routes at low and high $\mathrm{p}_{\mathrm{CO}}$, prior and after adaptation to high $\mathrm{CO}$ concentrations, are presented in Figures $\mathbf{5 A - C}$, respectively.

The disaggregation of the granular sludge showed a negative impact on their methanogenic activity, confirming that the acetoclastic methanogens were the most sensitive to $\mathrm{CO}$, and a contrario, the advantage of using granular sludge for further development toward largescale methane production from $\mathrm{CO}$-rich syngas or syngas biomethanation.

\section{AUTHOR CONTRIBUTIONS}

SS carried over the experiments, processed and interpreted the data, discussed the results and wrote the manuscript 
first draft. RC participated to the experimental design, to the processing, interpretation and discussion of the data, and reviewed the manuscript. GB lead the molecular biology studies, carried over the interpretation and discussion of the metagenomics results, and reviewed the manuscript. SG lead the project definition, participated to the experimental design and to the interpretation and discussion of the data, corrected and edited the final version of the manuscript.

\section{REFERENCES}

Abubackar, H. N., Veiga, M. C., and Kennes, C. (2015). Carbon monoxide fermentation to ethanol by Clostridium autoethanogenum in a bioreactor with no accumulation of acetic acid. Bioresource Tech. 186, 122-127. doi: 10.1016/j.biortech.2015.02.113

Alves, J. I., Stams, A. J. M., Plugge, C. M., Alves, M. M., and Sousa, D. Z. (2013). Enrichment of anaerobic syngas-converting bacteria from thermophilic bioreactor sludge. FEMS Microbiol. Ecol. 86, 590-597. doi: 10.1111/15746941.12185

Bagley, D. M., and Gossett, J. M. (1990). Tetrachloroethene transformation to trichloroethene and dichloroethene by sulfate-reducing enrichment cultures. Appl. Environ. Microbiol. 56, 2511-2516.

Banat, I. M., Lindström, E. B., Nedwell, D. B., and Balba, M. T. (1981). Evidence for coexistence of two distinct functional groups of sulfate-reducing bacteria in salt marsh sediment. Appl. Environ. Microbiol. 42, 985-992.

Bhatnagar, L., Krzycki, J. A., and Zeikus, J. G. (1987). Analysis of hydrogen metabolism in Methanosarcina barkeri: regulation of hydrogenase and role of CO-dehydrogenase in $\mathrm{H}_{2}$ production. FEMS Microbiol. Lett. 41, 337-343.

Borja, R., Sánchez, E., and Weiland, P. (1996). Influence of ammonia concentration on thermophilic anaerobic digestion of cattle manure in upflow anaerobic sludge blanket (UASB) reactors. Process Biochem. 31, 477-483. doi: 10.1016/0032-9592(95)00099-2

Braun, M., and Gottschalk, G. (1982). Acetobacterium wieringae sp. nov., a new species producing acetic acid from molecular hydrogen and carbon dioxide. Zentralbl. Bakteriol. Mikrobiol. Hyg. 1, 368-376.

Chidthaisong, A., and Conrad, R. (2000). Specificity of chloroform, 2bromoethanesulfonate and fluoroacetate to inhibit methanogenesis and other anaerobic processes in anoxic rice field soil. Soil Biol. Biochem. 32, 977-988. doi: 10.1016/S0038-0717(00)00006-7

Cord-Ruwisch, R., Lovley, D. R., and Schink, B. (1998). Growth of Geobacter sulfurreducens with acetate in syntrophic cooperation with hydrogen-oxidizing anaerobic partners. Appl. Environ. Microbiol. 64, 2232-2236.

Daniels, L., Fuchs, G., Thauer, R. K., and Zeikus, J. G. (1977). Carbon monoxide oxidation by methanogenic bacteria. J. Bact. 132, 118-126.

Diaz, E. E., Stams, A. J. M., Amils, R., and Sanz, J. L. (2006). Phenotypic properties and microbial diversity of methanogenic granules from a full-scale upflow anaerobic sludge bed reactor treating brewery wastewater. Appl. Env. Microbiol. 72, 4942-4949. doi: 10.1128/AEM.02985-05

Eaton, A. D., Clesceri, L. S., and Greenberg, A. E. (eds.). (1995). Standard Methods for the Examination of Water and Wastewater. Washington, D.C.: American Public Health Association.

Einen, J., Thorseth, I. H., and Ovreås, L. (2008). Enumeration of Archaea and Bacteria in seafloor basalt using real-time quantitative PCR and fluorescence microscopy. FEMS Microbiol. Lett. 282, 182-187. doi: 10.1111/j.15746968.2008.01119.x

Fang, H. H. P. (2000). Microbial distribution in UASB granules and its resulting effects. Water Sci. Technol. 42, 201-208.

Fang, H. H. P., Chui, H. K., and Li, Y. Y. (1994). Microbial structure and activity of UASB granules treating different wastewaters. Water Sci. Tech. 30, 87-96.

Ferry, J. G. (2010). CO in methanogenesis. Ann. Microbiol. 60, 1-12. doi: $10.1007 / \mathrm{s} 13213-009-0008-5$

\section{ACKNOWLEDGMENTS}

The authors wish to thank M.-J. Lévesque, P. Mehta, A. Corriveau, and S. Deschamps for their assistance. The study was partially supported by the Clean Energy Fund from the Office of Energy Research and Development (OERD) of Natural Resources Canada (project I12.017B). One author (SS) was supported by the Natural Sciences and Engineering Research Council of Canada (grant 185778-2009). Paper No. NRC-EME-55772.

Grabowski, A., Tindall, B. J., Bardin, V., Blanchet, D., and Jeanthon, C. (2005) Petrimonas sulfuriphila gen. nov., sp. nov., a mesophilic fermentative bacterium isolated from a biodegraded oil reservoir. Int. J. Syst. Evol. Microbiol. 55, 1113-1121. doi: 10.1099/ijs.0.63426-0

Guiot, S. R., Cimpoia, C., and Carayon, G. (2011). Potential of wastewater-treating anaerobic granules for biomethanation of synthesis gas. Environ. Sci. Technol. 45, 2006-2012. doi: 10.1021/es102728m

Guiot, S. R., Pauss, A., and Costerton, J. W. (1992). A structured model of the anaerobic granule consortium. Wat. Sci. Technol. 25, 1-10.

Guiot, S. R., Safi, B., Frigon, J.-C., Mercier, P., Mulligan, C., Tremblay, R., et al. (1995). Performances of a full-scale novel multiplate anaerobic reactor treating cheese whey effluent. Biotech. Bioeng. 45, 398-405. doi: 10.1002/bit.260450504

Hao, L.-P., Lü, F., He, P.-J., Li, L., and Shao, L.-M. (2011). Predominant contribution of syntrophic acetate oxidation to thermophilic methane formation at high acetate concentrations. Environ. Sci. Technol. 45, 508-513. doi: $10.1021 /$ es $102228 \mathrm{v}$

Henstra, A. M., Sipma, J., Rinzema, A., and Stams, A. J. M. (2007). Microbiology of synthesis gas fermentation for biofuel production. Cur. Op. Biotech. 18, 200-206. doi: 10.1016/j.copbio.2007.03.008

Hu, P., Bowen, S. H., and Lewis, R. S. (2011). A thermodynamic analysis of electron production during syngas fermentation. Bioresource Techn. 102, 8071-8076. doi: 10.1016/j.biortech.2011.05.080

Huber, G. W., Iborra, S., and Corma, A. (2006). Synthesis of transportation fuels from biomass: Chemistry, catalysts, and engineering. Chem. Rev. 106, 4044-4098. doi: 10.1021/cr068360d

Hwu, C.-S., Donlon, B., and Lettinga, G. (1996). Comparative toxicity of longchain fatty acid to anaerobic sludges from various origins. Water Sci. Technol. 34, 351-358. doi: 10.1016/0273-1223(96)00665-8

Johns, A. T. (1952). The mechanism of propionic acid formation by Clostridium propionicum. J. Gen. Microbiol. 6, 123-127.

Karakashev, D., Batstone, D. J., and Angelidaki, I. (2005). Influence of environmental conditions on methanogenic compositions in anaerobic biogas reactors. Appl. Environ. Microbiol. 71, 331-338. doi: 10.1128/AEM.71.1.331338.2005

Karakashev, D., Batstone, D. J., Trably, E., and Angelidaki, I. (2006). Acetate oxidation is the dominant methanogenic pathway from acetate in the absence of Methanosaetaceae. Appl. Environ. Microbiol. 72, 5138-5141. doi: 10.1128/AEM.00489-06

Klasson, K. T., Ackerson, E. C., Clausen, E. C., and Gaddy, J. L. (1991). Bioreactor design for synthesis gas fermentations. Fuel 70, 605-614.

Klasson, K. T., Cowger, J. P., Ko, C. W., Vega, J. L., Clausen, E. C., and Gaddy, J. L. (1990). Methane production from synthesis gas using a mixed culture of R. rubrum, M. barkeri, and M. formicicum. Appl. Biochem. Biotech. 24-25, 317-328.

Kliefoth, M., Langer, J., Matschiavelli, N., Oelgeschläger, E., and Rother, M. (2012). Genetic analysis of MA4079, an aldehyde dehydrogenase homolog, in Methanosarcina acetivorans. Arch. Microbiol. 194, 75-85. doi: 10.1007/s00203011-0727-4

Koster, I. W., and Lettinga, G. (1984). The influence of ammonium-nitrogen on the specific activity of pelletized methanogenic sludge. Agricult. Wastes 9, 205-216. doi: 10.1016/0141-4607(84)90080-5

Kozubal, M., Macur, R. E., Korf, S., Taylor, W. P., Ackerman, G. G., Nagy, A., et al. (2008). Isolation and distribution of a novel iron-oxidizing Crenarchaeon 
from acidic geothermal springs in Yellowstone National Park. Appl. Environ. Microbiol. 74, 942-949. doi: 10.1128/AEM.01200-07

Lee, M. J., and Zinder, S. H. (1988). Hydrogen partial pressure in a thermophilic acetate-oxidizing methanogenic coculture. Appl. Environ. Microbiol. 54, 1457-1461.

Lee, S., Malone, C., and Kemp, R. F. (1993). Use of multiple 16S rRNA-targeted fluorescent probes to increase signal strength and measure cellular RNA from natural planktonic bacteria. Mar. Ecol. Prog. Ser. 101, 193-201.

Lessner, D. J., Li, L., Li, Q., Rejtar, T., Andreev, V. P., Reichlen, M., et al. (2006). An unconventional pathway for reduction of $\mathrm{CO}_{2}$ to methane in $\mathrm{CO}$-grown Methanosarcina acetivorans revealed by proteomics. Proc. Natl. Acad. Sci. U.S.A. 103, 17921-17926. doi: 10.1073/pnas.0608833103

Lévesque, M. J., La Boissière, S., Thomas, J. C., Beaudet, R., and Villemur, R. (1997). Rapid method for detecting Desulftobacterium frappieri strain PCP1 in soil by the polymerase chain reaction. Appl. Microbiol. Biotechnol. 47, 719-725.

Liou, J. S. C., Balkwill, D. L., Drake, G. R., and Tanner, R. S. (2005). Clostridium carboxidivorans sp. nov., a solvent-producing clostridium isolated from an agricultural settling lagoon, and reclassification of the acetogen Clostridium scatologenes strain SL1 as Clostridium drakei sp. nov. Int. J. Syst. Evolution. Microbiol. 55, 2085-2091. doi: 10.1099/ijs.0.63482-0

Lü, F., Luo, C., Shao, L., and He, P.-J. (2016). Biochar alleviates combined stress of ammonium and acids by firstly enriching Methanosaeta and then Methanosarcina. Water Res. 90, 34-43. doi: 10.1016/j.watres.2015.12.029

Mazumder, T. K., Nishio, N., and Nagai, S. (1985). Carbon monoxide conversion to formate by Methanosarcina barkeri. Biotechnol. Lett. 7, 377-382.

McKendry, P. (2002). Energy production from biomass (part 3): Gasification technologies. Bioresource Techn. 83, 55-63. doi: 10.1016/S0960-8524(01) 00120-1

Mörsdorf, G., Frunzke, K., Gadkari, D., and Meyer, O. (1992). Microbial growth on carbon monoxide. Biodegradation 3, 61-82.

Muyzer, G., de Waal, E. C., and Uitterlinden, A. G. (1993). Profiling of complex microbial populations by denaturing gradient gel electrophoresis analysis of polymerase chain reaction-amplified genes coding for 16S rRNA. Appl. Environ. Microbiol. 59, 695-700.

Nicklin, J., Paget, T., Graeme-Cook, K., and Killington, R. A. (1999). Instant Notes in Microbiology. Oxford: Bios Scientific Pub Ltd.

Nozhevnikova, A. N., Nekrasova, V., Ammann, A., Zehnder, A. J. B., Wehrli, B., and Holliger, C. (2007). Influence of temperature and high acetate concentrations on methanogenensis in lake sediment slurries. FEMS Microbiol. Ecol. 62, 336-344. doi: 10.1111/j.1574-6941.2007.00389.x

O’Brien, J. M., Wolkin, R. H., Moench, T. T., Morgan, J. B., and Zeikus, J. G. (1984). Association of hydrogen metabolism with unitrophic or mixotrophic growth of Methanosarcina barkeri on carbon monoxide. J. Bacteriol. 158, 373-375.

Oelgeschläger, E., and Rother, M. (2008). Carbon monoxide-dependent energy metabolism in anaerobic bacteria and archaea. Arch. Microbiol. 190, 257-269. doi: 10.1007/s00203-008-0382-6

Oelgeschläger, E., and Rother, M. (2009). Influence of carbon monoxide on metabolite formation in Methanosarcina acetivorans. FEMS Microbiol. Lett. 292, 254-260. doi: 10.1111/j.1574-6968.2009.01492.x

Rother, M., and Metcalf, W. W. (2004). Anaerobic growth of Methanosarcina acetivorans $\mathrm{C} 2 \mathrm{~A}$ on carbon monoxide: an unusual way of life for a methanogenic archaeon. Proc. Nat. Acad. Sci. U.S.A. 101, 16929-16934. doi: 10.1073/pnas.0407486101

Sancho Navarro, S., Cimpoia, R., Bruant, G., and Guiot, S. R. (2014). Specific inhibitors for identifying pathways for methane production from carbon monoxide by a nonadapted anaerobic mixed culture. Can. J. Microbiol. 60, 407-415 doi: 10.1139/cjm-2013-0843

Schnürer, A., Zellner, G., and Svensson, B. H. (1999). Mesophilic syntrophic acetate oxidation during methane formation in biogas reactors. FEMS Microbiol. Ecol. 29, 249-261. doi: 10.1016/S0168-6496(99)00016-1

Schulz, S., and Conrad, R. (1996). Influence of temperature on pathways to methane production in the permanently cold profundal sediment of Lake Constance. FEMS Microbiol. Ecol. 20, 1-14. doi: 10.1111/j.15746941.1996.tb00299.x
Sekiguchi, Y., Kamagata, Y., Nakamura, K., Ohashi, A., and Harada, H. (1999). Fluorescence in situ hybridization using 16S rRNA-targeted oligonucleotides reveals localization of methanogens and selected uncultured bacteria in mesophilic and thermophilic sludge granules. Appl. Env. Microbiol. 65, $1280-1288$.

Shelobolina, E. S., Vrionis, H. A., Findlay, R. H., and Lovley, D. R. (2008). Geobacter uraniireducens sp. nov., isolated from subsurface sediment undergoing uranium bioremediation. Int. J. Syst. Evolut. Microbiol. 58, 1075-1078. doi: 10.1099/ijs.0.65377-0

Sipma, J., Henstra, A. M., Parshina, S. N., Lens, P. N. L., Lettinga, G., and Stams, A. J. M. (2006). Microbial CO conversions with applications in synthesis gas purification and bio-desulfurization. Crit. Rev. Biotech. 26, 41-65. doi: 10.1080/07388550500513974

Sipma, J., Lens, P. N. L., Stams, A. J. M., and Lettinga, G. (2003). Carbon monoxide conversion by anaerobic bioreactor sludges. FEMS Microbiol. Ecol. 44, 271-277. doi: 10.1016/S0168-6496(03)00033-3

Sipma, J., Meulepas, R. J. W., Parshina, S. N., Stams, A. J. M., Lettinga, G., and Lens, P. N. L. (2004). Effect of carbon monoxide, hydrogen and sulfate on thermophilic $\left(55^{\circ} \mathrm{C}\right)$ hydrogenogenic carbon monoxide conversion in two anaerobic bioreactor sludges. Appl. Microbiol. Biotech. 64, 421-428. doi: 10.1007/s00253-003-1430-4

Stineman, R. W. (1980). A consistently well-behaved method of interpolation. Creative Comput. 6, 54-57.

Techtmann, S. M., Colman, A. S., Murphy, M. B., Schackwitz, W. S., Goodwin, L. A., and Robb, F. T. (2011). Regulation of multiple carbon monoxide consumption pathways in anaerobic bacteria. Front. Microbiol. 2:147. doi: 10.3389/fmicb.2011.00147

Techtmann, S. M., Colman, A. S., and Robb, F. T. (2009). 'That which does not kill us only makes us stronger': the role of carbon monoxide in thermophilic microbial consortia. Environ. Microbiol. 11, 1027-1037. doi: 10.1111/j.14622920.2009.01865.x

Thauer, R. K., Jungermann, K., and Decker, K. (1977). Energy conservation in chemototrophic anaerobic bacteria. Bacteriol. Rev. 41, 100-180.

Tresse, O., Lorrain, J.-J., and Rho, D. (2002). Population dynamics of free-floating and attched bacteria in a styrene-degrading biotrickling filter analyzed by denaturing gradient gel electrophesis. Appl. Microbiol. Biotech. 59, 585-590. doi: 10.1007/s00253-002-1039-z

Tresse, O., Mounien, F., Lévesque, M.-J., and Guiot, S. R. (2005). Comparison of the microbial population dynamics and phylogenetic characterization of a CANOXIS reactor and a UASB reactor degrading the trichloroethene. J. Appl. Microbiol. 98, 440-449. doi: 10.1111/j.1365-2672.2004.02475.x

Welander, P. V., and Metcalf, W. W. (2005). Loss of the mtr operon in Methanosarcina blocks growth on methanol, but not methanogenesis, and reveals an unknown methanogenic pathway. Proc. Nat. Acad. Sci. U.S.A. 102, 10664-10669. doi: 10.1073/pnas.0502623102

Yu, J., and Pinder, K. L. (1993). Utilization of volatile fatty acids in methanogenic biofilms. Bioresource Tech. 46, 241-250. doi: 10.1016/0960-8524(93)90127-W

Zhang, X., and Bishop, P. L. (2003). Biodegradability of biofilm extracellular polymeric substances. Chemosphere 50, 63-69. doi: 10.1016/S0045-6535(02) 00319-3

Zhao, Y., Haddad, M., Cimpoia, R., Liu, Z., and Guiot, S. R. (2013). Performance of a Carboxydothermus hydrogenoformans-immobilizing membrane reactor for syngas upgrading into hydrogen. Int. J. Hydrogen Energy 38, 2167-2175. doi: 10.1016/j.ijhydene.2012.11.038

Conflict of Interest Statement: The authors declare that the research was conducted in the absence of any commercial or financial relationships that could be construed as a potential conflict of interest.

Copyright $\odot 2016$ Sancho Navarro, Cimpoia, Bruant and Guiot. This is an openaccess article distributed under the terms of the Creative Commons Attribution License (CC BY). The use, distribution or reproduction in other forums is permitted, provided the original author(s) or licensor are credited and that the original publication in this journal is cited, in accordance with accepted academic practice. No use, distribution or reproduction is permitted which does not comply with these terms. 